\title{
The Influence of Transformational Leadership and Interpersonal Trust on Innovative Work Behavior through Organizational Citizenship Behavior as a Mediation Variable
}

\author{
Istiqmal Fajar Danarjono $^{1}$, Farida Elmi ${ }^{2}$ \\ \{istiqmalfajar@gmail.com ${ }^{1}$, farida.elmi@mercubuana.ac.id² \\ Mercubuana University, Jakarta, Indonesia ${ }^{12}$
}

\begin{abstract}
Based on the data obtained, the level of innovative work behavior at PT. $\mathrm{XYZ}$ has decreased and not yet fully as expected. The purpose of this study was to explain the relationship of the independent variables, namely transformational Leadership and Interpersonal Trust, to the dependent variable, namely Innovative Work Behavior through the intervening variable, namely Organizational Citizenship Behavior (OCB). The research method used is quantitative using Structural Equation Model analysis. The results showed that (1) Transformational Leadership had no significant effect on OCB, (2) Interpersonal Trust had a significant effect on (OCB), (3) Transformational Leadership had a significant effect on Innovative Work Behavior, (4) Interpersonal Trust had a significant effect on Innovative Work Behavior, (5) OCB has a significant effect on Innovative Work Behavior, (6) Transformational Leadership and Interpersonal Trust together have a significant effect on OCB, (7) Transformational Leadership , Interpersonal Trust and OCB together have a significant effect on Innovative Work Behavior, (8) OCB partially mediates Transformational Leadership and Interpersonal Belief in Innovative Work Behavior because it only partially mediates Interpersonal Trust in Innovative Work Behavior, does not mediate Transformational Leadership on Innovative Work Behavior.
\end{abstract}

Keywords: The Effect Authentic Leadership, Trust, Work Autonomy, Member's Performance

\section{Introduction}

In this digital era, individuals, groups, organizations and countries are indirectly required to have high competitiveness. To be able to compete in the digital era, one way to do innovation. Based on Bilal Afsar's (2019) research, he stated that Innovative Work Behavior is an important factor for increasing competitive advantage such as developing new ideas, new technology and new methods related to procedures in certain areas. A country becomes innovative because of the ideas, creativity, and innovation created from many levels of society which are implemented in various fields such as academia, industry and manufacturing such as PT. XYZ. 


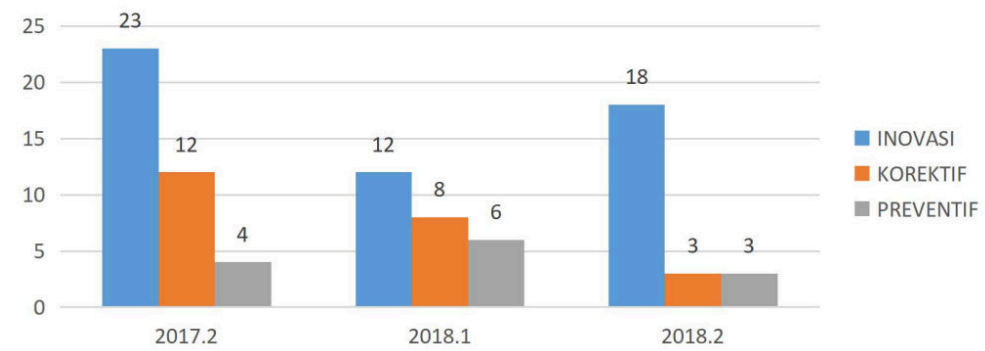

Fig1. Management Review PT. XYZ

Based on data management review at PT. XYZ, seen the level of innovation at PT. XYZ decreased in the first smester of 2018, then there was an increase in the second smester of 2018, but the innovations made were not as high as 2017. Bilal Afsar (2019) said that an organization needs to develop innovation to meet the problems and challenges that arise such as increasing customer expectations, market changes and also because of increased competition both locally and globally. According to the research results of Hui Lei et al (2019), Transformational Leadership has a positive effect on innovative work behavior. The pre-survey conducted on 30 respondents indicated that the individual manager's attention to employees was low, this data is in accordance with the training report which shows a significant decrease in training in the second semester in 2018.

In addition, the results of research by Yang, et al. (2018) state that interpersonal trust also affects innovative work behavior. Pre-survey results indicate that employees have a high level of trust. The highest dimension is "Honesty" with a figure of $93.55 \%$. Previous research conducted by Arief Anshari (2018) also stated that OCB affects innovative work behavior. It can be seen that employees have a high level of OCB in the pre-survey results regarding OCB, the smallest number is in "concentiousness" $(80.65 \%)$. The data is in accordance with the characteristics of respondents where the majority of employees who work are aged 25 to 35 years $(51.62 \%)$ which is the productive age.

However, research conducted by Uhl-Bien, (2018) obtained inconsistent results and there were also findings showing high variation between Transformational Leadership and innovative work behavior, researchers questioned the relationship between Transformational Leadership and Innovative Work Behavior to be considered through a mediator or through a moderation so that transformational leaders can influence innovative work behavior. Because of the importance of innovative work behavior, the authors are interested in conducting research "The Influence Of Ransformational Leadership And Interpersonal Trust On Innovative Work Behavior Through Organization Citizenship Behavior (Ocb) As A Mediation Variables".

\subsection{Innovation Work Behavior}

According to Rank (2004) in a research conducted by Bilal Afsar (2019), innovative work behavior is an activity related to proposed development, development planning and implementation of innovation for every level of the organization. De Jong \& Den Hartog (2010: 24) say that the operational process of innovative work behavior is a multi-stage process, namely: Idea Exploration, Idea Generation, Idea Selection Struggle, and Idea Implementation. 


\subsection{Transformational leadership}

According to Robbin \& Judge (2015: 261) transformational leaders inspire followers to go beyond self-interest for the benefit of the organization. According to Bass (1990) in Wirawan (2013: 7), transformational leadership is an attempt by leaders to transform followers from a low level of need to a higher level of need. The dimensions of Transformational Leadership according to Bass are: Ideal Influence, Inspirational Motivation, Intellectual Simulation, and Individual Attention.

\subsection{Interpersonal Trust}

According to Ken \& Ali's research (2017), trust is something that cannot be separated from individual interactions with others. A person trusts another person based on the information received. Trust becomes important in the relationship between managers and employees, who have different roles and varying degrees of status and power. In Rottenberg's (2010: 9-10) theoretical model, to understand the concept of interpersonal trust, there is an Interpersonal Trust framework in the BDT model (Bases, Domains, and Targets), based on this model, there are 3 basic dimensions of Interpersonal Trust, namely: Reliability, Emotion, and Honesty.

\subsection{Organizational Citizenship Behavior (OCB)}

According to Robbins and Judge (2015: 19) Organizational Citizenship Behavior (OCB) is freedom behavior that is not part of the requirements of work, but contributes to the psychological and social environment in the workplace. There are two main things related to Organizational Citizenship Behavior (OCB), namely OCBI and OCBO, Organizational Citizenship Behavior of Individual (OCBI) refers to behavior that immediately benefits certain individuals in an organization, thus contributing indirectly to organizational effectiveness. Organizational Citizenship Behavior of Organization (OCBO), which is the second dimension of Organizational Citizenship Behavior (OCB), is a behavior that can make an organization benefit without actions specifically aimed at members. MacKenzie (1990: 134) in Kelly L (2015: 402) states that the indicators of Organizational Citizenship Behavior are as follows: Altruisme, Conscientiousness, Sportmanship, Courtesy, Civic Virtue..

\section{Research Method}

According to research by Heni, et al (2018), Transformational Leadership has a positive effect on Organizational Citizenship Behavior (OCB). According to research by Lebbaeus Asamani (2017), Ni Nyoman (2018) and Lei Hui (2018), it shows that there is a positive and significant relationship between interpersonal trust and employee Organizational Citizenship Behavior. This is because interpersonal trust allows employees to work in ways that are not fully controlled by their superiors. According to Tse, et al (2018), Transformational Leadership can enhance innovative work behavior. Research by Lei Hui (2018), Dewa Nyoman (2018) and Fathul Himam (2018) also shows that there is a positive and significant relationship between Transformational Leadership and employee innovative work behavior. According to Ni Nyoman's (2018) research, there is a positive and significant relationship between interpersonal trust and employee innovative work behavior. 
According to Anshari's (2018) research, there is a positive and significant relationship between Organizational Citizenship Behavior (OCB) attitudes towards innovative work behavior. This research is a quantitative research at PT. XYZ. Employees at PT. XYS is a population where the number is 280 people. The sample size is 165 respondents, and uses SEM-PLS analysis technique because the total number of respondents is above 100 so it requires non-parametric analysis or does not require various assumptions. To determine the number of samples, this study uses the Slovin theory approach (Yusuf, 2014: 170):



\section{Results and Discussion}

The outer model is used to see how valid and how reliable the indicators used in this study are. Convergent validity evaluation using Average variance extracted (AVE), is used to describe the amount of variance or variety of manifest variables that can be owned by latent constructs, the expected AVE value is greater than 0.5. Evaluation of convergent validity uses internal consistency reliability and is seen from the value of Cronbach's Coefficient Alpha (CA) and Composite Reliability (CR). The expected CA and CR values are $>0.7$. The results of the measurement of AVE, CA and CR values can be seen in Table 1.

Table 1. Average Variance Extracted (AVE), Cronbach's Coefficient Alpha (CA) and Composite Reliability (CR) Value

\begin{tabular}{lclc}
\hline Variables & Value AVE & Value CA & Value CR \\
\hline Transformational Leadership & 0.558 & 0.888 & 0.909 \\
Interpersonal Trust & 0.601 & 0.902 & 0.922 \\
$\begin{array}{l}\text { Organizational Citizenship } \\
\text { Behavior (OCB) }\end{array}$ & 0.543 & 0.894 & 0.914 \\
\hline
\end{tabular}




\begin{tabular}{cccc}
\hline Innovative Work Behavior & 0.552 & 0.884 & 0.908 \\
\hline Source: Data processed by Researchers $(2020)$ & &
\end{tabular}

Table 1 shows that the AVE values for all variables are $>0.5,0.558$ for Transformational Leadership, 0.601 for interpersonal trust, 0.543 for OCB, and 0.552 for innovative work behavior. The Cronbach's Coefficient Alpha value and the Composite reliability value for all research variables were more than 0.7 , some were even more than 0.9 . This value is in accordance with the minimum limit, each value is more than 0.7 , so that all variables in this study are reliable. To evaluate the structural model (inner model) or hypothesis testing, this study takes the following steps: evaluating the path coefficient value, evaluating the R2 value, measuring the effect size $\mathrm{f} 2$, validate the entire structural model using the Goodness of Fit Index (GoF), and test using predictive relevance (Q2).

To evaluate the effect, the researcher uses the path coefficient, based on the results of calculations with SmartPLS version 3.0 bootstrapping, the path coefficient results show the strength of the construct relationships, as shown in Table 2. Comparison of tcount with ttable and comparison of Pcount and PStandard with the following conditions:

a. If tcount is greater than tTable and Pcount is smaller than PStandard, the hypothesis is accepted.

b. If the amount of tcount is smaller than tTable and the of Pcount is greater than the Pstandard, the hypothesis is rejected.

Table 2. Path Coefficient Test Results

\begin{tabular}{|c|c|c|c|c|}
\hline $\begin{array}{l}\text { Hypothesis. } \\
\text { Interpretation } \\
\end{array}$ & $\begin{array}{l}\text { Coefficient } \\
\text { Path }\end{array}$ & $\begin{array}{l}\text { TCount }_{\text {Con }}> \\
\mathbf{t}_{\text {Tabel }}\end{array}$ & $\begin{array}{l}\text { P. Count }< \\
\text { P. Standard }\end{array}$ & Information. \\
\hline $\mathrm{H}_{1 .} \mathrm{KT} \gg>\mathrm{OCB}$ & 0.065 & $1.138<1.654$ & $0.256>0.05$ & Rejected \\
\hline \multirow{3}{*}{$\begin{array}{l}\mathrm{H}_{2} . \mathrm{KI}>\mathrm{OCB} \\
\mathrm{H}_{3} . \mathrm{KT}>>\text { PKI } \\
\mathrm{H}_{4} \mathrm{KI}>>\text { PKI }\end{array}$} & 0.804 & $21.058>1.654$ & $0<0.05$ & \multirow{3}{*}{$\begin{array}{l}\text { Accepted } \\
\text { Accepted } \\
\text { Accepted }\end{array}$} \\
\hline & 0.112 & $2.267>1.654$ & $0.024<0.05$ & \\
\hline & 0.36 & $3.53>1.654$ & $0<0.05$ & \\
\hline $\mathrm{H}_{5} . \mathrm{OCB} \gg \mathrm{PKI}$ & 0.477 & $5.143>1.654$ & $0<0.05$ & Accepted \\
\hline
\end{tabular}

Source: Data processed by Researchers (2020)

Table 2 shows that the most influential variable is interpersonal trust with Organizational Citizenship Behavior, while the path that has no effect is Transformational Leadership with Organizational Citizenship Behavior. The results of statistical calculations (part 2) are presented in Table 3. The tools used for testing the hypothesis (part 2) using the R2 test and comparison of fCount with fTable, the hypothesis is accepted with the following conditions:

1. If. f. Count. is. Greater. than. f. Table, the. Hypothesis. is accepted.

2. If. f. Count is. Less. Then. F. Table, the. Hypothesis. Is. rejected.

Table 3. R2 Test Results

\begin{tabular}{lllcr}
\hline Hypothesis. Interpretation & $\boldsymbol{R}^{\mathbf{2}}$ & $\mathbf{F}_{\text {Count }}>\mathbf{f}_{\text {Table }}$ & Alpha & Information \\
\hline $\mathrm{H}_{6 .}$ KT \& KI $>>$ OCB & 0.704 & $127.64>2.66$ & 0.05 & Accepted \\
$\mathrm{H}_{7 .}$ KT, KI \& OCB $>>$ PKI & 0.75 & $161>2.66$ & 0.05 & Accepted \\
\hline
\end{tabular}

The results of the direct effect and indirect effect of the independent variable on the Innovative Work Behavior variable are presented in table 4. The hypothesis is accepted with the following conditions: 
a. If the path coefficient of Transformational Leadership interpersonal trust and Organizational Citizenship Behavior from direct effect to indirect effect does not change, the hypothesis is rejected.

b. If the path coefficient of Transformational Leadership interpersonal trust and Organizational Citizenship Behavior from direct effect to indirect effect decreases, the hypothesis is rejected.

c. If the path coefficient between Transformational Leadership interpersonal trust and Organizational Citizenship Behavior from direct effect to indirect effect increases, the hypothesis is accepted.

Table 4. Effect of Independent Variables on Dependent Variables

\section{$\begin{array}{lll}\text { Hypothesis. interpretation } & \text { Coefficient Path (DE) }<\quad \text { Information }\end{array}$}

\begin{tabular}{lll}
\hline $\mathrm{H}_{8} \mathrm{KT}$ and $\mathrm{KI}$ to PKI through OCB & $0.112>0.031$ & Rejected \\
as variable mediation & $0.36<0.384$ & Accepted \\
\hline
\end{tabular}

Source: Data processed by Researchers (2020)

a. Obtained a path coefficient of 0.065 and tcount (1.138) <tTable (1.654) with a Pvalue of 0.256 (Pcount $>0.05$ ), thus $\mathrm{H} 1$ is rejected and $\mathrm{H} 0$ is accepted, it can be concluded that Transformational Leadership has an effect on Organizational Citizenship Behavior but not significant, the higher the Transformational Leadership style can affect the Organizational Citizenship Behavior in working with an insignificant percentage because it only affects $6.5 \%$.

b. Obtained a path coefficient of 0.804 and tcount $(21.058)>$ ttable $(1,654)$ with pcount of 0.000 , so $\mathrm{H} 2$ is accepted $(\mathrm{p}<0.05)$ and $\mathrm{H} 0$ is rejected, Interpersonal trust has a significant effect on Organizational Citizenship Behavior.

c. Obtained path coefficient of 0.112 and tcount $(2.267)>$ thable (1.654) with Pcount of 0.024 , thus $\mathrm{H} 3$ is accepted $(\mathrm{P}<0.05)$ and $\mathrm{H} 0$ is rejected, Transformational Leadership has a significant effect on Innovative Work Behavior.

d. Obtained a path coefficient of 0.36 and tcount (3.53)> tTable (1.654) with pcount of 0.000 , thus $\mathrm{H} 4$ is accepted $(\mathrm{p}<0.05)$ and $\mathrm{H} 0$ is rejected, Interpersonal trust has a significant effect on innovative work behavior.

e. Obtained a path coefficient of 0.477 and tcount $(5,143)>$ ttable $(1,654)$ with pcount of 0.000 , thus H5 is accepted (Pcount $<0.05$ ) and H0 is rejected, Organizational Citizenship Behavior is significant on innovative work behavior.

f. Transformational Leadership and Interpersonal Trust variables have a value of R2 0.704 with an fCount of 127.64 and a value of fTable 2.66. This means that fCount (127.64) > fTable (2.66), then $\mathrm{H} 6$ is accepted and $\mathrm{H} 0$ is rejected.

g. The variables of Transformational Leadership, Interpersonal Trust and Organization Citizenship Behavior have a value of R2 0.75 with a value of fcount 161 and fTable 2.66. This means that fCount (161)> fTable (2.66), then $\mathrm{H} 7$ is accepted and $\mathrm{H} 0$ is rejected.

h. The path coefficient value of the direct effect of Transformational Leadership on Innovative Work Behavior is $0.112>$ the path coefficient value of the indirect effect of Transformational Leadership on Innovative Work Behavior is 0.031, and the Pvalue is calculated as the indirect influence of Transformational Leadership variables on Innovative Work Behavior mediated by the Organization Citizenship Behavior variable. 
is $0.232>$ PStandard 0.05 and tcount $1.196<$ tTable 1.654 , it can be concluded that the indirect effect of Transformational Leadership on Innovative Work Behavior is not mediated by the Organization Citizenship Behavior variable, this indicates that Transformational Leadership can improve Innovative Work Behavior although without going through the Organization Citizenship Behavior variable.

In theory, Transformational Leadership has an effect on Organizational Citizenship Behavior, such as the opinion of Luthans (2006: 654) in Ratya, et al. (2016) that Transformational Leadership produces an indirect effect on Organizational Citizenship Behavior (OCB), but the results of this study are not in accordance with the results. Previous research conducted by Heni, et al. (2018) stated that Transformational Leadership has a significant effect on Organizational Citizenship Behavior, but the results of this study are in accordance with the research conducted by Ratya, et al. (2016), where the study stated that leadership has no significant effect. against Organizational Citizenship Behavior. According to Ratya, et al. (2016), Transformational Leadership is not always suitable for use, application and acceptance in all places because in certain conditions transactional leadership is more necessary.

This result is in accordance with the characteristics of the respondents where the majority of respondents' education is high school graduates. High school education level or equivalent understands more about technical things that are usually done in work, where the Organizational Citizenship Behavior that arises is not from Transformational Leadership factors, but Organizational Citizenship Behavior that may arise from other factors such as internal factors. Interpersonal trust makes employees work in a way that is not fully controlled by their superiors, thus the results of this study support the results of previous studies conducted by Lebbaeus Asamani (2017), Ni Nyoman (2018) and Lei Hui (2018) which show that there are a positive and significant relationship between interpersonal trust in employee Organizational Citizenship Behavior. if the interpersonal trust is high, it will increase the Organizational Citizenship Behavior of employees.

This research supports the results of research by Tse, et al. (2018) and the results of previous studies conducted by Lei Hui (2018) which show that Transformational Leadership has a significant effect on Innovative Work Behavior, high or low transformation of a leader, will affect the Innovative Work Behavior of employees. These results support some of the results of previous studies and consistent with the results of Ni Nyoman's (2018) research which shows that there is a positive and significant relationship between interpersonal trust and innovative work behavior.

\section{Conclusions}

Transformational Leadership has no significant effect on Organization Citizenship Behavior, that's result impact Organization Citizenship Behavior only mediates Interpersonal Trust in Innovative Work Behavior, and does not mediate Transformational Leadership on Innovative Work Behavior. According to the characteristics of respondents where the majority of respondents' education is high school graduates. High school education level or equivalent understands more about technical things that are usually done in work, where the Organizational Citizenship Behavior that arises is not from Transformational Leadership factors, but Organizational Citizenship Behavior that may arise from other factors such as internal factors.

Based on the results of this study, further research should be able to dig deeper into the variables that influence innovative work behavior and variables that mediate innovative work 
behavior. The results of this study open the possibility of other influences from Organization Citizenship Behavior (OCB) on other variables such as leader-member exchanges, transactional leadership and organizational commitment.

\section{References}

[1] Arief Anshari, Nurdin Brasit, Nurdjanah Hamid (2018). Pengaruh Leader Member Exchange (LMX) dan Organizational Citizenship Behavior (OCB) terhadap Innovative Work Behavior (IWB) untuk meningkatkan kinerja Organisasi. Jurnal Bisnis, Manajemen dan Informatika (2018)

[2] Bilal Afsar \& Waheed Ali Umrani. (2019). Transformational Leadership and Innovative Work Behavior The role of motivation to learn, task complexity and innovation climate. European Journal of Innovation Management.

[3] Farida, Elmi. (2018). Telisik Manajemen Sumber Daya Manusia. Mitra Wacana Media.

[4] Hui Lei, Sengphet Phouvong, Phong Ba Le. (2019). How to foster innovative culture and capable champions for Chinese firms. Chinese Management Studies Vol. 13 No. 1, 2019 pp. 51-69.

[5] Hui Lei, Thuong Thi Nguyen, Phong Ba Le. (2019). How knowledge sharing connects interpersonal trust and innovation capability: The moderating effect of leadership support. Chinese Management Studies.

[6] Hui Lei, Sengphet Phouvong, Le Ba Phong. (2018). Transformational Leadership Facilitates Innovation Capability: The Mediating Roles of Interpersonal Trust. International Journal of Business Administration.

[7] Heni Awanti, Aziz Fathoni, Djamaludin Malik. (2018). Pengaruh Kepemimpinan Transformasional, Kepuasan Kerja dan Komitmen Organisasi terhadap Organizational Citizenship Behavior. Semarang (2018).

[8] Lebbaeus Asamani. (2017). Interpersonal Trust at Work and Employees' Organizational Citizenship Behavior. International Journal of Business and Management Review, Vol.3, No.11, pp.17-29.

[9] Ni Nyoman Surya Cahyani \& Ayu Desi Indrawati. (2018). Peran Kepercayaan pada Pengawas Memediasi Pengaruh Pemberdayaan Karyawan terhadap Perilaku Kerja Inovatif. E-Jurnal Manajemen Unud, Vol. 7, No. 11, 2018: 6360 - 6390.

[10] Weiping Jiang* , Xianbo Zhao, Jiongbin Ni (2017). The Impact of Transformational Leadership on Employee Sustainable Performance: The Mediating Role of Organizational Citizenship Behavior. Sustainability 2017, 9, 1567.

[11] Zhi Yang, Van Thithuy Nguyen, Phong Ba Le. (2018). Knowledge sharing serves as a mediator between collaborative culture and innovation capability: an empirical research. Journal of Business \& Industrial Marketing, Vol. 33 Issue: 7, pp.958-969. 